\title{
The Divided Self, Hidden Values, and Moral Sensibility in Medicine
}

\section{Citation}

Kleinman, Arthur Michael. 2011. The divided self, hidden values, and moral sensibility in medicine. The Lancet 377(9768): 804-805.

\section{Published Version}

doi:10.1016/S0140-6736(11)60295-X

\section{Permanent link}

http://nrs.harvard.edu/urn-3:HUL.InstRepos:9133073

\section{Terms of Use}

This article was downloaded from Harvard University's DASH repository, and is made available under the terms and conditions applicable to Open Access Policy Articles, as set forth at http:// nrs.harvard.edu/urn-3:HUL.InstRepos:dash.current.terms-of-use\#OAP

\section{Share Your Story}

The Harvard community has made this article openly available.

Please share how this access benefits you. Submit a story.

Accessibility 
Final manuscript version sent to The Lancet on Jan. 272011.

The Divided Self and Hidden Values: Education for Moral Sensibility in Medicine and for the

\section{Rest of Life}

Arthur Kleinman

Harvard University

$\underline{\text { kleinman@wjh.harvard.edu }}$ 
The idea of modernity has long been associated with a paired idea of a divided self. Sigmund

Freud, Pierre Janet, William James, W.H.R. Rivers and many, many writers, artists, musicians, filmmakers, critics and intellectuals from the end of the $19^{\text {th }}$ century up to the present have advanced this increasingly global cultural picture of the individual's interiority as split and discordant, if not downright contradictory. The way the self is seen to be divided can be as different as the oppositions in conscious/unconscious, cognitive/affective, moral calling/transgressive desire, this-worldly/other-wordly, violation/redemption, "once born" to optimism/"twice born" to a harder, more pessimistic orientation, and so on. While this metaphor is a bad fit when applied to schizophrenia (whose very name was intended to embody the idea), it remains a commonplace figure in the humanities for making sense of a chaotically complex world and equally complex personhood that is portrayed as fractured and at odds with itself. The irony and doubt that are so characteristic of how modernity is represented in literature and art are lodged in these bent fragments of self and world. 
Oddly, when physicians, ethicists, decision analysts and policy makers debate value questions in clinical care and public health, this is not their way of taking the individual's subjectivity into account. Instead, the dominant metaphor of the self for health services researchers and health policy experts is usually a stick-figure character with simple and predictable responses to local contexts like family or clinical settings, a caricature who says what he/she means and means what he/she says without an anxious blink or an ironic wink. Even the local worlds he or she inhabits are usually presented straightforwardly in thinned out case reports and best practice guidelines in an overly superficial, homogenized and too-reduced-to-be-real way. This biomedical and bioethical structure of cases and treatment algorithms isn't just an inadequate presentation of the thickness and disconnections of human conditions; it is a core distortion of what it means in real life clinical and home settings for individuals to work out responses to serious illnesses and demanding treatments. 
Not least of these distortions is the way lived values - the actual practices and engagement over what really matters in a particular place and time among vexed patients, families and clinicians - are represented as clear-cut choices over admittedly fraught, yet simplistic, unidimensional value questions such as the ethical framing of the messiness and unclarity of end-oflife decisions as straightforward questions of futility versus heroic interventions.

What gets lost in this construction of the classic medical scenario are divided emotions and hidden, conflicted values. In my experiences as clinician and ethnographer, but also as patient and primary caregiver, for a wife who is in the terrible terminality of Alzheimer's Disease, practioners and even family members are better prepared by our culture and our health care systems to express and respond to lists of stereotypes and clear-cut rules than they are ready to deal with divided emotions and hidden values. 
Think of young residents and clinical students on medical rounds who privately disagree with the assessment and clinical plan set out by attending physicians but who are unable or unwilling to express dissent because of fear of the repercussions on their careers. And adding to this sad state, the attending him or herself may be of two minds but uncertain whether expression of the contradiction he or she feels will confuse and demoralize his/her trainees. Or put yourself in the place of patients and family members who fail to express or disguise what really matters to them because they fear it will create problems in their interactions with doctors and nurses, or upset carefully balanced family relations. Perhaps an adult son or daughter, whose remaining parent is entering the terminal stage of Alzheimer's Disease and for whom he or she is the health proxy and legal guardian, disagrees with what their parent had laid out in advance directives, but is uncertain or psychologically unprepared to openly express his or her disagreement and advocate for a personal position. Perhaps they too are of two minds but don't know how to project the contradiction without exposing themselves to ridicule or creating an impasse in caregiving. And when they are dealt with by clinicians who themselves have been taught to elicit and respond to 
simple value alternatives, those patients get the further dispiriting sense that their value conflicts are best kept hidden.

What I am saying is that values tied to emotions require a sensibility about how our selves and worlds are divided and hide what is most at stake. That few of us in medicine are educated to articulate and deal with hidden and divided values is what I have learned over nearly a half century; and yet in everyday life this is how most people including us somehow learn to get along by strategizing over when to reveal and when to conceal the contradictions we inhabit. Hidden and divided values when unaddressed clinically can come to undermine personal lives and clinical interactions creating inauthentic and false scenarios for teaching about, clinically engaging and working out policies for caregiving. This may be the more subtle yet more fundamental conflict of interest in medicine. 
I think this is why medical students transit so easily from the "pre-cynical" first few years of medical school to the "cynical" years on wards and in clinics - a transition that many educators recognize is an unintended consequence, a disabling effect of medical education. They are taught rules and methods that go out the window when those students appear on the wards and in clinics where danger and uncertainty are vividly alive, expediency reigns supreme and caregiving gives way to getting the work done fast. Absent a moral sensibility of what clinical work should be in a world of divided and hidden values, idealistic students are remade as cynics, much like the residents and attendings they emulate. And I also think this is why there is increasing suspicion and distrust among the public of what physicians and policy experts really value in health system reform. That is, self interest in career advancement, efficiency, cost control and profits are suspected to lie behind words about quality of care as the not so disguised, hypocritical primary values of health care professionals. 
Of course, the notion of a divided self with hidden values also seems useful as a trope for articulating the Janus-faced experience of the physician as simultaneously a professional and a particular person with his or her own deep subjectivity. Here the hidden conflict is between what the professional persona seems to demand and what the personhood of that professional actually feels but cannot or will not speak.

Is there a way of resolving or at least lessening the consequences of this problem? I believe there is, and it begins with the paideia of the student: the ancient Greek ideal of the cultural constitution of the educated person; similar to what the Confucian tradition speaks of as the cultivation of inner values that completes our humanity. The ideal or virtue I have in mind is education for a moral sensibility of critical self-reflection in caregiving. It is that sensibility about the pressure of conflicting feelings and values, in both person and context, and how to identify, articulate and tinker with them in real life encounters so as to be a better caregiver that I 
have come to understand is a crucial but too often unrecognized requirement in clinical education and in the rest of life.

Hence what medical students need to develop is critical self-reflection on their own hidden and divided values and those of their patients and patients' families. I personally don't believe this can be achieved through curricula that lack serious attention to the medical humanities (anthropology, history, literature, the arts). Film, biography, social history, the novel, and ethnography cultivate this crucial clinical sensibility. So do experience in music, art museums, and humanistic psychotherapy. Somehow those subjects and experiences need to be present in clinical training and also made available for continuing medical education. Just as important, health care systems need to find means to encourage the practioners' practice of critical self reflection while caregiving on a regular basis. This is essential if we are to make medicine more humane via the sensibility of the practitioner. And much the same can be said for physicians working at health services reform and health policy. Learning to picture the world, the patient 
and his or her physician as divided and harboring hidden (and, at times, conflicting) values is the intellectual complement to the practical interpersonal skills of kindness, respect, compassion, and communicative competence that put together with technical competence contribute what it should mean to be a physician. Skills at critical self-reflection on the complexity and irony of what really matters in living also can enrich life, because this paideia and cultivation of sensibility alerts us to the rest of life beyond medicine, where uncertainty, danger and balancing happiness and disappointment are just as thoroughly caught up with our divided selves and hidden values as they are in the clinic. Yet, the pedagogy that works well in basic science education and technical training in clinical work is, in my view, not just inadequate for cultivating a sensibility of critical self-reflection as part of caregiving, but actually contributes to undermining it.

The pedagogy for engaging hidden values and divided selves is the moral building of the clinician as a fully-developed human being. Such pedagogy uses the humanities not to educate 
students to be social scientists, humanists, or ethicists, but instead to cultivate and develop a deeper, richer and more receptive sensibility: critical, aesthetically alert and morally responsive.

It is this sensibility that animates and is animated by the everyday practice of caregiving; and it is this same sensibility that makes the rest of life, well, more liveable.

I do not mean to make this sound utopian. The knowledge is there. The methodology is practical. The constraints on time, though real enough, can be dealt with. Numerous beginning students come in passionate about these things; and even jaded academics know that something must be done to build the moral life of practitioners and strengthen caregiving. There are even some good, if limited in scale, examples. The financial cost, while real, is not insurmountable. It comes down to a questions of what it is we really value.

References for Further Reading 
Werner Jaeger: Paideia: The Ideals of Greek Culture. Volume II In Search of the Divine Centre.

Translated by Gilbert Highest. Oxford: Basil Blackwell, 1957.

Henry James: Preface to The Wings of the Dove. London: Penguin Books, 2008 [1902]

William James: The Varieties of Religious Experience. Cambridge, MA: Harvard University

Press, 1985 [1902].

Arthur Kleinman: The Illness Narratives. New York: Basic Books, 1988.

Arthur Kleinman: What Really Matters: Living a Moral Life Amidst Uncertainty and Danger.

Oxford and New York: Oxford University Press, 2006. 
Mencius: (Mengzi): translated by D.C. Lau. London, New York: Penguin Books, 2004 